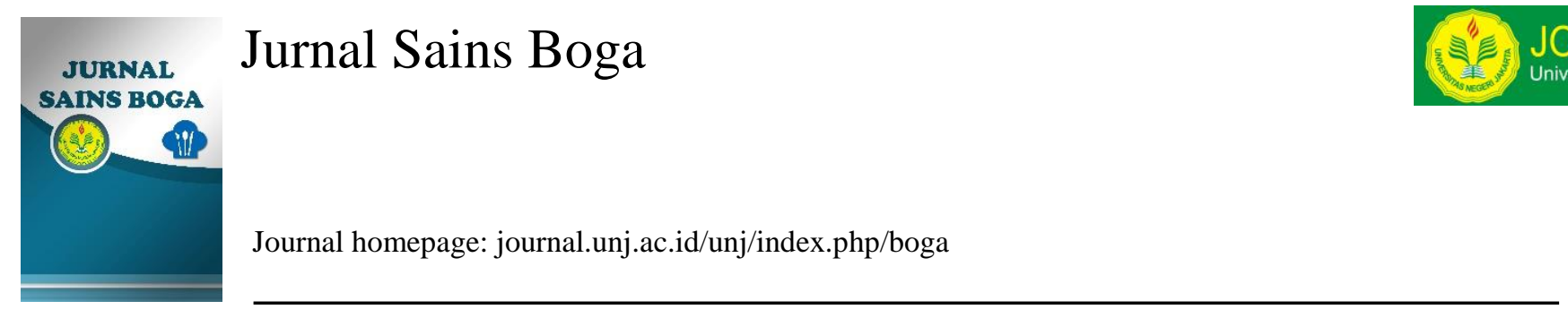

\title{
Exclusion of Dietary Cholesterol From The Specific Food Restrictions: A Review in Indonesia
}

\author{
Mirza Rizqi Zulkarnain ${ }^{1, *)}$ \\ ${ }^{1)}$ Department of Food Technology, Faculty of Life Science, International University Liaison Indonesia, IULI - \\ Eco Campus, MyRepublic Plaza, The Breeze, BSD City 15345 \\ *) corresponding author: mirza.zulkarnain@lect.iuli.ac.id
}

\begin{abstract}
Hypercholesterolemia, the presence of high levels of cholesterol in the blood, is one of the major risk factor for cardiovascular disease (CVD). One of the key recommendation in the Dietary Guidelines for Americans 2010, is to consume less than $300 \mathrm{mg}$ of dietary cholesterol per day. The same amount is also adopted in Indonesia (BPOM, 2016) until today. However, in the latest Dietary Guidelines for Americans 2015-2020, dietary cholesterol is no longer included in the list of specific foods that should be limited. The added sugars, sodium, saturated fats and trans fats remain on the list of food components that should be reduced. Generally, foods that are higher in dietary cholesterol are also higher in saturated fats. But there are also some foods that are higher in cholesterol but not in saturated fats. According to the latest recommendation, this kind of foods can be consumed without any specific restriction. In this review, some of clinical studies related to the association between dietary cholesterol and blood cholesterol levels are selected. The findings from those studies will be summarized to consider whether the same recommendation should be implemented in other countries, especially in Indonesia.
\end{abstract}

Keywords: cholesterol; cardiovascular disease; dietary cholesterol; dietary guidelines; hypercholesterolemia; Indonesia; plasma cholesterol; serum cholesterol

\section{INTRODUCTION}

High serum cholesterol is a major risk factor for cardiovascular disease (CVD). CVD is still a major cause of global death and diet plays a crucial role in the prevention and pathology of the disease (Lordan et al, 2018). Cholesterol indeed plays an important role in the development of atherosclerosis (Imes and Austin, 2013). It could leads to clogged arteries and therefore lead to CVD (Wardlaw et al, 2012). The association between high serum cholesterol concentration and risk for CVD has lead to dietary restrictions of cholesterol-rich foods (Mahan and Stump, 2004). Previously, in the Dietary Guidelines for Americans 2010, the intake of dietary cholesterol is limited to less than $300 \mathrm{mg}$ per day. The same number of limitation is also adopted in Indonesian's Nutrition Label Reference by Badan Pengawas Obat dan Makanan (BPOM, 2016). However, in the latest Dietary Guidelines for Americans 2015-2020 and the Scientific Report of the 2015 Scientific Guidelines Advisory Committee, dietary cholesterol is no longer included in the list of nutrients of concern for 
over consumption, while the added sugars, sodium, saturated fats and trans fat are still remain on the list of specific foods that need to be restricted to obtain the optimum health and prevent the dietrelated chronic diseases. Not all countries have implemented the same recommendation in their dietary guidelines (FAO, 2017). This exclusion of dietary cholesterol is also not yet applied in Indonesia. The objective of this review is to summarize some of clinical studies related to the association between dietary cholesterol and blood cholesterol levels, and determine whether the same recommendation should be applied in other countries, especially in Indonesia.

\section{Cholesterol}

Cholesterol is the main steroid of mammals and occurs in lipids in free form or esterified with saturated and unsaturated fatty acids (Belitz et al, 2009). It forms parts of cells, some hormones, and bile acids (Wardlaw et al, 2012). It also have other roles as a precursor of vitamin D (7dehydrocholesterol) in the skin by ultraviolet irradiation and bile acids (Damodaran et al, 2008). The body acknowledges those importance functions in its capacity of both absorbing dietary cholesterol and synthesizing cholesterol. Since it can be synthesized in the body, there is no absolute need for dietary intake, but homeostasis helps maintain a stable pool of cholesterol.

Two major sources available for absorption of the intraluminal cholesterol are the diet and the bile. All biliary cholesterol is nonesterified (free) and much more likely to be absorbed than esterified cholesterol. The proportion of free versus esterified cholesterol varies between different food sources. The fraction of cholesterol in the intestines which is absorbed varies from $15 \%$ to $75 \%$, and group averages are about 50\%, with the remainder excreted in the feces (Cohn et al, 2010). The majority (up to 70-80\%) of circulating cholesterol is from endogenous synthesis (Hegele, 2009). When dietary cholesterol intake is very low, its synthesis and absorption are up-regulated, while if dietary intake is too high, biliary and intestinal excretion will also be intensified. Therefore, synthesis and absorption of cholesterol are negatively correlated (Lecerf and Lorgeril, 2011).

\section{Plasma Cholesterol}

Plasma cholesterol level is the result of intestinal cholesterol absorption and hepatic cholesterol synthesis, also biliary excretion and cellular use (Lecerf and Lorgeril, 2011). It is affected by numerous factors, including age, diets, and other factors such as genetics, endogenous sex hormones (absence in postmenopausal women or presence during menstrual cycle), exogenous steroids (anabolic or sex hormones), drugs ( $\beta$-blocker, thiazide diuretics), body weight, glucose tolerance, physical activity level, disease (diabetes, thyroid, liver) and season of the year.

Lipoprotein is a compound found in the bloodstream containing a core of lipids with a shell composed of protein, phospholipid, and cholesterol. There are four groups of lipoproteins: chylomicron, very-low-density lipoprotein (VLDL), low-density lipoprotein (LDL), and high-density lipoprotein (HDL) with the composition and function as listed in table 1. A standard lipoprotein profile includes measurement of total cholesterol, LDL cholesterol, HDL cholesterol and triglyceride levels after 8-12 hours fasting to allow time for chylomicrons to clear (Mahan and Stump, 2004). A normal lipoprotein profile is a total cholesterol level less than $200 \mathrm{mg} / \mathrm{dl}$, LDL cholesterol less than $130 \mathrm{mg} / \mathrm{dl}$, HDL cholesterol is more than $40 \mathrm{mg} / \mathrm{dl}$ and triglyceride level less than $150 \mathrm{mg} / \mathrm{dl}$ (NCEPATP III, 2001).

Table 1. The composition and function of Lipoprotein (Wardlaw et al, 2012)

\begin{tabular}{lll}
\multicolumn{1}{c}{ Lipoprotein } & \multicolumn{1}{c}{ Primary Component } & \multicolumn{1}{c}{ Key Role } \\
\hline Chylomicron & Trigliseride & Carries dietary fat from the small intestine to cells \\
VLDL & Trigliseride & Carries lipids made and taken up by the liver to cells \\
LDL & Cholesterol & $\begin{array}{l}\text { Carries cholesterol made by the liver and from other } \\
\text { sources to cells } \\
\text { HDL }\end{array}$ \\
Protein & $\begin{array}{l}\text { Contributes to cholesterol removal from cells and } \\
\text { excretion of it from the body }\end{array}$ \\
\hline
\end{tabular}


Dyslipidemia is the abnormal lipid metabolism, including the elevation or reduction of lipid fraction in plasma. The major abnormal lipid fraction is the elevation of total cholesterol, LDL cholesterol and triglyceride and the reduction of HDL cholesterol (Thompson et al, 2011). HDL cholesterol is often called "good cholesterol" while LDL cholesterol is often called "bad cholesterol".

\section{Dietary Cholesterol}

Dietary cholesterol is found only from animal sources (Wardlaw et al, 2012). The examples of dietary cholesterol can be seen in table 2 (Almatsier, 2007). Eggs are the one of the main dietary sources for cholesterol. Some high cholesterol foods are also contains high amount of saturated fats, such as butter, lard, pork and cheese. In the other hand, there are many foods that contains high cholesterol but only small amount of saturated fat (such as: eggs, lamb, chicken, fish) or even contains no saturated fat at all (such as: shrimp, liver, and brain).

Table 2. Some Foods Containing Cholesterol (Almatsier, 2007)

\begin{tabular}{lccc}
\multicolumn{1}{c}{ Foods } & $\begin{array}{c}\text { Total Fat } \\
(\mathbf{g} / \mathbf{1 0 0 g})\end{array}$ & $\begin{array}{c}\text { Saturated Fat } \\
(\mathbf{g} / \mathbf{1 0 0 g})\end{array}$ & $\begin{array}{c}\text { Cholesterol } \\
(\mathbf{m g} / \mathbf{1 0 0 g})\end{array}$ \\
\hline Beef & 14 & 5.1 & 70 \\
Lamb & 9.2 & 3.6 & 70 \\
Pork & 35 & 11.3 & 70 \\
Chicken & 25 & 0.9 & 60 \\
Fish & 4.5 & 1 & 70 \\
Egg & 11.5 & 3.7 & 550 \\
Shrimp & 0.2 & - & 125 \\
Liver & 3.2 & - & 300 \\
Brain & 8.6 & - & 2000 \\
Cow's Milk & 3.5 & 1.8 & 11 \\
Full Cream Powder Milk & 30 & 16.3 & 85 \\
Cheese & 20.3 & 11.3 & 100 \\
Butter & 81.6 & 44.1 & 250 \\
Lard & 100 & 28.4 & 95 \\
\hline
\end{tabular}

Cholesterol responsiveness are widely varies among individuals. In the hyperresponders people, their serum cholesterol is more responsive to dietary cholesterol challenge than the hyporesponders people. Individuals with initially higher cholesterol concentrations also have been found to be more responsive to a cholesterol-lowering diet than those with lower cholesterol concentrations. People also differ in terms of the intensity of cholesterol synthesis (Lecerf and Lorgeril, 2011). Some people may be hyperabsorbers of cholesterol while others may be hyperproducers (Senaratne et al, 2012).

\section{Latest Recommendation from The United States Department of Agriculture (USDA)}

In February 2015, the USDA Dietary Guidelines Advisory Committee (DGAC) revised the old recommendation to limit cholesterol intake. In contrary to the previous recommendation in Dietary Guidelines for Americans (DGA) 2010 to limit dietary cholesterol less than $300 \mathrm{mg}$ per day, the new Dietary Guidelines for Americans (DGA) 2015-2020 excludes dietary cholesterol from the list of nutrients of concern for over consumption. In the latest recommendation from USDA, only added sugars, saturated fats \& sodium intake that should be limited. Based on this latest recommendation, dietary cholesterol is no longer a concern for over consumption. Dietary guidelines in Australia, 
Canada, New Zealand, Korea, India and European countries also do not set any upper limit for cholesterol intake (Fernandez, 2012). Dietary cholesterol restrictions also has been dropped by Dietary Guidelines for Chinese Residents (Wang et al, 2016). However, not all countries have implemented the same recommendation in their dietary guidelines (FAO, 2017).

In general, foods that are higher in dietary cholesterol are also higher in saturated fats. The USDA Food Patterns that are limited in saturated fats are also low in dietary cholesterol. Thus, individuals should eat as little dietary cholesterol as possible while consuming a healthy eating pattern. Only few foods, such as egg yolks and some shellfish, are higher in dietary cholesterol but not in saturated fats. Therefore, according to the latest Dietary Guidelines for Americans (2015-2020), eggs and shellfish can be consumed along with a variety of other protein foods group.

USDA Food Patterns recommend to limit the intake of added sugar and solid fats because they are not nutrient dense and solid fats contribute to saturated fat intake. Excess sodium is associated with several adverse health events, particularly hypertension. Saturated fat is still a nutrient of concern for overconsumption, particularly for those older than the age of 50 years.

The DGAC used the 2013 American Heart Association/American College of Cardiology (AHA/ACC) report on lifestyle management to reduce cardiovascular disease (CVD) risk for its evaluation of saturated fat intake (Eckel et al, 2014). The saturated fat intake exceeds current recommendations in the United States and that lower levels of consumption would further reduce the population level risk of CVD. The replacement of saturated fatty acids (SFA) by polyunsaturated fatty acids (PUFA) in the diet is associated with a reduced risk of CVD is generally accepted (Astrup et al, 2011). When PUFAs replace SFAs, the evidence from epidemiologic, clinical, and mechanistic studies are consistent that the risk of CHD is reduced (Mozaffarian et al, 2010).

Trans fatty acids is produced by hydrogenated vegetable oils and can be found naturally in animal fats. A number of studies have observed an association between increased intake of trans fats and increased risk of CVD due to its LDL-cholesterol-raising effect. The FDA (2015) has determined that partially hydrogenated oils (such as: in margarines), which are the primary dietary source of trans fats, are no longer included in generally recognized as safe (GRAS) category, with compliance expected by June 18, 2018. In one of the study included in the review article by Ooi et al (2015), five weeks consumption of trans fatty acids was associated with higher total and LDL cholesterol, and lower HDL cholesterol concentrations in post-menopausal women. Increased dietary intake of industrial trans fats is associated with an increased risk in all cause mortality, CVD and type-2 diabetes (Souza et al, 2015).

\section{Implementation in Indonesia}

Republic of Indonesia (RI) is a country located in Southeastern Asia, an archipelago between the Indian and Pacific Ocean. The total number of islands in the archipelago is 13,466, of which 922 are permanently inhabited (CIA, 2018). It is the fourth largest population country in the world, with over 260 millions of people (estimation by June 2017). According to the latest update in 2014 from Kementrian Dalam Negeri (Ministry of Internal Affairs) RI, Indonesia has 34 provinces and 508 districts. So far, there have been several basic health researches and nutrition survey were conducted in Indonesia, such as Riset Kesehatan Dasar (Riskesdas) in 2007, 2010 and 2013 conducted by Kementrian Kesehatan (Ministry of Health) RI, and also South East Asian Nutrition Survey (SEANUTS) Study in 2011.

The SEANUTS study in Indonesia was conducted in a nationwide representative sample of 7211 children using a cross-sectional study design in 48 districts to provide the latest data on nutritional status, food consumption and biochemical parameters related to nutrition for children aged 6 months -12 years (Sandjaja et al, 2013). However, no lipid profile data was collected in Indonesia (Schaafsma et al, 2013). Riskesdas was also a cross-sectional study, the latest one (2013) has been done to 294.959 households in 33 provinces and 497 districts in Indonesia to provide evidence-based information for the formulation of health development policies at different levels of administration. Serum cholesterol data was one of the data collected in $\geq 15$ years old subjects. The prevalence of abnormal total cholesterol level was $35.9 \%$, low HDL was $22.9 \%$, non optimal LDL was $60.3 \%$ (with near optimal-high borderline category), and $15.9 \%$ (high and very high category), the abnormal triglyceride was $13 \%$ (high borderline category) and $11.9 \%$ (high-very high category). The national 
proportion of population with the behaviour of consuming the fatty, cholesterol and fried foods $\geq 1$ times per day were $40.7 \%$ and the prevalence of CVD appears to increase with the age of respondents. The next Riskesdas will be conducted in 2018.

In accordance to USDA Recommendation, Pedoman Gizi Seimbang (PGS) 2014 from Kementrian Kesehatan (Ministry of Health) RI stated that too sweet, too salty and too fatty foods need to be limited. According to The Ministry of Health Regulation (2013), sugar consumption for more than $50 \mathrm{~g}$ (4 tablespoon), sodium more than $2000 \mathrm{mg}$ ( 1 teaspoon) and fat /oils more than $67 \mathrm{~g}$ ( 5 tablespoon) per individual per day will increase the risk of hypertention, stroke, diabetes, heart attack. The information of sugar, sodium and fat content and all the nutrition fact must be stated in the food label and must be readable by the intended consumers.

For the food products, Badan Pengawas Obat dan Makanan (BPOM) as the Food and Drugs Administration (FDA) in Indonesia recently in 2016 has updated the Regulation for Nutrition Label Reference (BPOM, 2016). In this latest version, the cholesterol reference is still less than $300 \mathrm{mg}$ per day, similar to the previous recommendation from USDA in 2010. It means that for Indonesians, dietary cholesterol is still a concern.

According to Pedoman Gizi Seimbang (PGS) 2014, the consumption of fats and oils in everyday meals should be no more than $25 \%$ of energy consumption. Nationally, the average fat consumption in Indonesia is still in accordance with the recommendation which is 47 grams/ capita/ day or $25 \%$ of total energy consumption. Its characteristics are greater in the group of population aged 2-18 years, living in urban areas and in the group of women (Riskesdas, 2010).

The other recommendation from Perhimpunan Dokter Spesialis Kardiovaskular Indonesia (Indonesian Cardiologist Association) in 2013, diet that can be applied to reduce LDL cholesterol is unsaturated fatty acids diet such as mono unsaturated fatty acids (MUFA) and polyunsaturated fatty acids (PUFA) because the major factor contributed to the LDL cholesterol level is saturated fatty acids (SFA). Consumption of omega 3 PUFA in pharmacologic dosage ( $>2$ g/day) have a neutralizing effect towards LDL cholesterol concentration and reduce triglyceride (TG).

\section{METHODS}

A search of the scientific literature was used to identify studies related to the association between dietary cholesterol and plasma cholesterol published in the last two decades (from 1997 to 2017). The keywords were "cholesterol", "dietary cholesterol", "plasma cholesterol", "blood cholesterol", "hypercholesterolemia", "Indonesia", "diet kolesterol", "kolesterol", "kolesterol darah" using various databases and by reviewing reference lists. Clinical studies that were selected in this review are various types of studies, including intervention studies, review article, systematic review and metaanalyses. In vitro studies, animal studies and intervention studies using certain medication (such as statin) were excluded. The result of those studies were tabulated and summarized to consider whether the exclusion of dietary cholesterol from the specific food restrictions should also be implemented to other countries, especially in Indonesia.

\section{RESULTS AND DISCUSSION}

There have been numerous researches conducted about cholesterol, but only limited studies related to the association between dietary cholesterol and plasma cholesterol. Most of the intervention studies used eggs as the dietary source of cholesterol. The author has not found any intervention study related to the association between dietary cholesterol with plasma cholesterol level that conducted for the local population in Indonesia.

From the above summary of studies related to the association between dietary cholesterol with plasma cholesterol level (table 3), only few studies indicated that the dietary cholesterol intake can raise the plasma cholesterol level. Most of those studies published earlier. In the meta analysis study performed by Clarke et al (1997), it was indicated that in typical British diets, replacing $60 \%$ of saturated fats by other fats and avoiding $60 \%$ of dietary cholesterol would reduce blood total cholesterol by about $0.8 \mathrm{mmol} / \mathrm{l}$ (that is, by $10-15 \%$ ), with four fifths of this reduction being in LDLcholesterol. In the meta-analysis study performed by Weggemans et al (2001), the result showed that 
the dietary cholesterol raises the ratio of total to HDL cholesterol and adversely affects the cholesterol profile. Thus, the dietary cholesterol intake may still need to be limited. One of the study published in 2013 by Griffin and Linchstein also suggested that the restriction of dietary cholesterol intake is likely warranted. There is also one study in Chinese population published recently (Pang et al, 2017) indicated that serum total cholesterol (TC) and low density lipoprotein cholesterol (LDL-C) were related to dietary cholesterol intake, with each $100 \mathrm{mg}$ increase in dietary cholesterol intake apparently leading to a $0.035 \mathrm{mmol} / \mathrm{L}(\mathrm{p}=0.001)$ increase in serum TC and a $0.038 \mathrm{mmol} / \mathrm{L}(\mathrm{p}<$ 0.001 ) increase in LDL-C.

Table 3. Selected Clinical Studies Related to the Association between Dietary Cholesterol and Plasma Cholesterol Level

\begin{tabular}{|c|c|c|}
\hline Year & Researchers & Objective \\
\hline 1997 & $\begin{array}{lccc}\text { Clarke } & \mathrm{R}, & \text { Frost } & \mathrm{C}, \\
\text { Collins } \mathrm{R}, & \text { Appleby } & \mathrm{P}, \\
\text { Peto R. } & & & \end{array}$ & $\begin{array}{l}\text { To determine the quantitative } \\
\text { importance of dietary fatty acids and } \\
\text { dietary cholesterol to blood } \\
\text { concentrations of total, LDL, and } \\
\text { HDL cholesterol. }\end{array}$ \\
\hline 2000 & McNamara DJ & $\begin{array}{l}\text { To re-evaluate the basic assumptions } \\
\text { involved in dietary cholesterol and } \\
\text { egg restrictions. }\end{array}$ \\
\hline
\end{tabular}

2000 Song WO, Kerver JM PL, Katan MB
2001 Weggemans RM, Zock

To assess the nutritional significance of eggs in the American diet and to estimate the degree of association between egg consumption and serum cholesterol concentration.

To review the effect of dietary cholesterol on the ratio of total to HDL cholesterol.

2005 Greene, CM, Zern,TL, Wood, RJ, Shrestha, S, Aggarwal, D, Sharman, MJ, Volek JS and Fernandez, ML

2006 Qureshi, AL, Suri, MF, Ahmed, S., Nasar, A., Divani,AA, Kirmani, JF.

2007 Volk, M. G.

2010 Njike V, Faridi Z, Dutta S, Gonzalez-Simon AL, Katz D.

2010 Isherwood C, Wong C, To undertake a dietary intervention Jones W, Davies I, to determine the effects of cold Griffin B
To evaluate the effects of a cholesterol challenge on plasma cholesterol, LDL size, and LDL susceptibility to oxidation in the elderly.

To examine the association between egg consumption and risk of cardiovascular diseases and mortality

To summarize studies that researched fat intake and cardiovascular mortality

To assess the effects of egg consumption on endothelial function and serum lipids in hyperlipidemic adults.

water prawns on plasma lipids and lipoproteins.
Result* saturated fats by other fats and avoiding $60 \%$ of dietary cholesterol would reduce blood total cholesterol by about $0.8 \mathrm{mmol} / \mathrm{l}$ (that is,by 10-15\%), with four fifths of this reduction being in low density lipoprotein cholesterol.

Addition of $100 \mathrm{mg}$ cholesterol per day to the diet increases total cholesterol (1.9 $\mathrm{mg} / \mathrm{dL}$ in LDL and $0.4 \mathrm{mg} / \mathrm{dL}$ in HDL). On average, the LDL:HDL ratio change per $100 \mathrm{mg} /$ day change in dietary cholesterol is from 2.60 to 2.61 , which have little effect on heart disease risk.

Egg consumption made important nutritional contributions to the American diet and was not associated with high serum cholesterol concentrations.

Dietary cholesterol raises the ratio of total to HDL cholesterol and adversely affects the cholesterol profile. The advice to limit cholesterol intake may therefore still be valid.

Dietary cholesterol provided by eggs does not increase the risk for heart disease in a healthy elderly population.

Consumption of $>6$ eggs/wk did not increase the risk for stroke

Recent research indicated that dietary cholesterol is not reflected in serum levels.

Egg consumption was found to be nondetrimental to endothelial function and serum lipids in hyperlipidemic adults, while egg substitute consumption was beneficial.

The consumption of prawns produced no significant effects on the concentration of plasma total or LDL cholesterol, triacylglycerol, HDL cholesterol or 


\begin{tabular}{|c|c|c|}
\hline Year & Researchers & Objective \\
\hline 2011 & Lecerf, JM \& Lorgeril, M & Not specified \\
\hline 2013 & $\begin{array}{ll}\text { Griffin, } & \text { J. } \\
\text { Lichtenstein, } & \text { A. H. }\end{array}$ & $\begin{array}{l}\text { To address the relationship between } \\
\text { dietary cholesterol and plasma } \\
\text { lipoprotein profilesin randomized } \\
\text { control trials published within the } \\
\text { past } 20 \text { years. }\end{array}$ \\
\hline
\end{tabular}

2014 Made, S.M., Kelly, E. To assess the effects of 1-y daily R., Berendschot, T. T. J. consumption of lutein-rich egg yolks M, Kijlstra, A., on plasma lutein concentrations, Lutjohann, D. \& Plat, J. MPOD, and visual function in participants with early AMD and to evaluate the effects of long-term daily egg yolk consumption on serum lipids and lipoproteins to estimate changes in CVD risk.

2016 Clayton, ZS, Fusco, E., To summarize the documented Kern, M.

2017 Kim, JE \& Campbell, WW

2017 Pang SJ, Jia SS, Man QQ, Song S, Li YQ, Song PK, Zhao WH and Zhang J health risks of egg consumption in individual with low and high risk of CVD and determine whether the current recommendations are based on the available literature and provide guidence for future studies

To assess the effect of co-consuming cooked whole eggs on dietary cholesterol absorption in adults

To assess the status of dietary cholesterol intake and its food sources.

\section{Result*}

apolipoproteins A-I and B relative to the control, or within each intervention group over time.

Recent epidemiological studies have not shown any relationship between cardiovascular risk and dietary cholesterol intake and/or egg consumption, or else have shown a very low effect, except in diabetic subjects.

The effect of dietary cholesterol on plasma lipids concentrations, with primary interest in LDL-C, is modest and limited to population subgroups. In these cases, restrictions in dietary cholesterol intake are likely warranted.

Changes in serum total, HDL, and LDL cholesterol, as well as the ratio of total cholesterol to HDL cholesterol, were not different between the 2 groups (egg group and control group)

It is important to utilize various approaches for future studies to understand how eggs affect human health

The findings from 2 studies indicated that the dietary cholesterol in whole eggs was not well absorbed and did not affect plasma total cholesterol concentration.

Serum total cholesterol (TC) and low density lipoprotein cholesterol (LDL-C) were related to dietary cholesterol intake, with each $100 \mathrm{mg}$ increase in dietary cholesterol intake apparently leading to a $0.035 \mathrm{mmol} / \mathrm{L}(\mathrm{p}=0.001)$ increase in serum TC and a $0.038 \mathrm{mmol} / \mathrm{L}(\mathrm{p}<0.001)$ increase in LDL-C.

*Related to the association between dietary cholesterol and plasma cholesterol level.

Most of other recently published studies found no significant association between dietary cholesterol intake with the plasma cholesterol level. In many studies, eggs as a source of dietary cholesterol can be consumed without significant effect on plasma cholesterol level. A review study done by McNamara (2000) showed that dietary cholesterol is not related to coronary heart disease (CHD) incidence or mortality across or within populations. A cross-sectional and population-based study done by Song and Kerver (2000) showed that egg consumption made important nutritional contributions to the American diet and was not associated with high serum cholesterol concentrations. In a randomized crossover trial conducted by Greene et al (2005), eggs does not increase the risk for CVD in a healthy elderly population. A published cohort study by Qureshi et al (2006) indicated that consumption of greater than 6 eggs per week (average of 1 egg or greater per day) does not increase the risk of stroke and ischemic stroke. All relevant studies (cohort and crosspopulation) summarized by Volk (2007) in a review article indicated that dietary cholesterol is not 
reflected in serum levels. In a randomized, placebo-controlled crossover trial done by Njike et al (2010), they found no detrimental effect of eggs consumption to endothelial function and serum lipids in hyperlipidemic adults. Lecerf and Lorgeril also stated in their review article (2011) that recent epidemiological studies have not shown any relationship between cardiovascular risk and dietary cholesterol intake and/or egg consumption, or else have shown a very low effect, except in diabetic subjects. A randomized, double-blind, placebo-controlled study conducted by Made et al (2014) showed no different between 2 intervention groups (egg group and control group). According to Clayton et al (2016), in a review study about egg consumption and heart health, it is important to utilize various approaches for future studies to understand how eggs affect human health. Results from two randomized controlled crossover trials conducted by Kim and Campbell (2017) indicated that the dietary cholesterol in whole eggs was not well absorbed and did not affect plasma total cholesterol concentration. Cold water prawns that also used as source of dietary cholesterol in one of the intervention study conducted by Isherwood et al (2010) also showed no significant effect on the concentration of plasma total or LDL cholesterol, triacylglycerol, HDL cholesterol or apolipoproteins A-I and B relative to the control, or within each intervention group over time.

\section{CONCLUSION}

Within two decades, there are only limited number of studies related to the association between dietary cholesterol and plasma cholesterol. From the above summary, so far no strong scientific evidence support the association between dietary cholesterol intake with high level of plasma cholesterol (hypercholesterolemia). However, the new recommendation from USDA about the exclusion of dietary cholesterol from the specific food restriction should be carefully considered before being implemented in other countries. Some people clearly are more hyper-responsive to dietary cholesterol than others. Furthermore, need to educate the society about the source of food containing dietary cholesterol with low saturated fats and trans fat, because alot of food that contain high cholesterol also contain high saturated fats and trans fats. Foods that contains high cholesterol but low saturated fat could be broad field for intervention studies to see the effect of dietary cholesterol in plasma cholesterol level. More extensive studies on hyper-responders, the systematic review and meta-analyses to determine the association between dietary cholesterol and plasma cholesterol level are still needed for future research especially for the local population, before the exclusion of dietary cholesterol from the specific food restrictions is ready to be implemented in other countries, particularly in Indonesia.

\section{ACKNOWLEDGEMENT}

The review and its interpretation have been done independently. There is no specific grant from any funding agency in the public, commercial or non-commercial sectors. This article does not contain any studies with human or animal subjects performed by the author. There is no conflict of interest.

\section{REFERENCES}

Almatsier, S. 2007. Editor. Penuntun Diet Instalasi Gizi RS Cipto Mangunkusumo dan Asosiasi Dietisien Indonesia. PT. Gramedia Pustaka Utama. Jakarta.

Astrup A, Dyerberg J, Elwood P, Hermansen K, Hu FB, Jakobsen MU, Kok FJ, Krauss RM, Lecerf JM, LeGrand P, Nestel P, Rise 'rus U, Sanders T, Sinclair A, Stender S, Tholstrup T, and Willett WC. 2011. The role of reducing intakes of saturated fat in the prevention of cardiovascular disease: where does the evidence stand in 2010? Am J Clin Nutr 2011;93:684-8.

Belitz, HD, Grosch, W, Schieberle, P. 2009. Food Chemistry 4th revised and extended ed. SpringerVerlag Berlin Heidelberg. DOI: 10.1007/978-3-540-69934-7

Central Intelligence Agency (CIA). 2018. The World Fact Book: Indonesia. https://www.cia.gov/library/publications/the-world-factbook/geos/id.html [17 March 2018]. 
Clarke R, Frost C, Collins R, Appleby P, Peto R. 1997. Dietary lipids and blood cholesterol: quantitative meta-analysis of metabolic ward studies. Br Med J. ;314:112-7.

Clayton, ZS, Fusco, E., Kern, M. 2016. Egg consumption and heart Health: A review. Nutrition 37: 79-85. DOI: 10.1016/j.nut.2016.12.014

Cohn, JS, Kamili, A, Wat, E, Chung, RWS, Tandy, S. 2010. Dietary phospholipids and intestinal cholesterol absorption. Nutrients, 2(2), 116-127. DOI: 10.3390/nu2020116.

Damodaran S, Parkin KL, Fennema OR. 2008. Fennema's Food Chemistry 4th edition. Taylor \& Francis, CRC Press.

Eckel RH, Jakicic JM, Ard JD, de Jesus JM, Houston Miller N, Hubbard VS, Lee IM, Lichtenstein AH, Loria CM, Millen BE, Nonas CA, Sacks FM, Smith SC Jr, Svetkey LP, Wadden TA, Yanovski SZ. 2014. 2013 AHA/ACC Guideline on Lifestyle Management to Reduce Cardiovascular Risk. A Report of the American College of Cardiology/American Heart Association Task Force on Practice Guidelines. J Am Coll Cardiol. 2014 Jul 1;63(25 Pt B):30273028. DOI: 10.1016/j.jacc.2013.11.003.

FAO. 2017. Food-based dietary guidelines. http://www.fao.org/nutrition/nutritioneducation/food-dietary-guidelines/en/ [25 September 2017].

FDA. 2015. Final Determination Regarding Partionally Hydrogenated Oils. Federal Register. June 17,2015;80(116):34650-34670. Available at: https://www.federalregister.gov/documents/2015/06/17/2015-14883/final-determinationregarding-partially-hydrogenated-oils. [8 March 2018].

Fernandez ML. 2012. Rethinking Dietary Cholesterol. Current Opinion in Clinical Nutrition and Metabolic Care. March 15(2):117-121. DOI: 10.1097/MCO.0b013e32834d2259.

Greene CM, Zern TL, Wood RJ, Shrestha S, Aggarwal D, Sharman MJ, Volek JS and Fernandez ML. 2005. Maintenance of the LDL Cholesterol:HDL Cholesterol Ratio in an Elderly Population Given a Dietary Cholesterol Challenge. J. Nutr. 135: 2793-2798.

Griffin JD, Lichtenstein AH. 2013. Dietary cholesterol and plasma lipoprotein profiles: randomizedcontrolled trials. Curr Nutr Rep. December ; 2(4): 274-282. DOI: 10.1007/s13668-013-0064-0.

Hegele RA. 2009. Plasma lipoproteins: Genetic influences and clinical implications. Nature Reviews Genetics. 2009; 10(2):109-121.10.1038/nrg2481.

Imes CC, Austin MA. 2013. Low-density lipoprotein cholesterol, apolipoprotein B and risk of coronary heart disease: from familial hyperlipidemia to genomics. Biol Res Nurs. 2013 July ; 15(3): 292-308. . DOI: 10.1177/1099800412436967.

Isherwood C, Wong C, Jones W, Davies I, Griffin B. 2010. Lack of effect of cold water prawns on plasma cholesterol and lipoproteins in normo-lipidaemic men. Cellular and Molecular Biology. 2010; 56:52-58.

Kementrian Dalam Negeri RI. 2014. Direktorat Penataan Daerah, Otonomi Khusus, dan Dewan Pertimbangan Otonomi Daerah Direktorat Jenderal Otonomi Daerah Pembentukan DaerahDaerah Otonom di Indonesia sampai dengan tahun 2014. http://otda.kemendagri.go.id/CMS/Images/SubMenu/total_daerah_otonom.pdf [17 March 2018]

Kementerian Kesehatan RI. 2010. Riset Kesehatan Dasar (Riskesdas) 2010. Badan Penelitian dan Pengembangan Kesehatan, Jakarta.

Kementerian Kesehatan RI. 2013. Riset Kesehatan Dasar (Riskesdas) 2013. Badan Penelitian dan Pengembangan Kesehatan, Jakarta.

Kementrian Kesehatan RI. 2014. Pedoman Gizi Seimbang. 
Kim JE \& Campbell WW. 2017. Dietary cholesterol contained in whole eggs is not well absorbed and does not affect plasma total cholesterol concentration in men and women: results from two randomized controlled crossover trials. The FASEB Journal vol. 31 no. 1 Supplement 137.4

Lecerf, J. M., and Lorgeril, M. 2011. Dietary cholesterol: from physiology to cardiovascular risk. British Journal of Nutrition, 106, 6-14.

Lordan, L, Tsoupras A, Mitra B, Zabetakis, I. 2018. Dairy Fats and Cardiovascular Disease: Do We Really Need to be Concerned? Foods 2018, 7, 29; DOI:10.3390/foods7030029.

Mahan K., and Stump SE. 2004. Krause's Food, Nutrition \& Diet Therapy. $11^{\text {th }}$ edition. USA: Elsevier.

Made SM, Kelly ER, Berendschot TTJM, Kijlstra A, Lutjohann D and Plat J. 2014. Consuming a buttermilk drink containing lutein-enriched egg yolk daily for 1 year increased plasma lutein but did not affect serum lipid or lipoprotein concentrations in adults with early signs of age-related macular degeneration. J. Nutr. 144: 1370-1377

McNamara, DJ. 2000. The impact of egg limitations on coronary heart disease risk: do the numbers add up? J Am Coll Nutr Oct;19(5 Suppl):540S-548S.

Mozaffarian D, Micha R, Wallace S. 2010. Effects on coronary heart disease of increasing polyunsaturated fat in place of saturated fat: a systematic review and meta-analysis of randomized controlled trials. PLoS Med 2010;7:e1000252.

NCEP-ATP III. 2001. Third Report of the National Cholesterol Education Program (NCEP) Expert Panel on Detection, Evaluation , and Treatment of High Blood Colesterol in Adults (Adult Treatment Panel III). Executive Summary. NIH Publication No. 01-3670.

Njike, V. Faridi, Z., Dutta, S., Gonzalez-Simon, AL, Katz, D. 2010. Daily egg consumption in hyperlipidemic adults - Effects on endothelial function and cardiovascular risk. Nutrition Journal 9:28.

Pang SJ, Jia SS, Man QQ, Song S, Li YQ, Song PK , Zhao WH and Zhang J. 2017. Dietary Cholesterol in the Elderly Chinese Population: An Analysis of CNHS 2010-2012. Nutrients 2017, 9, 934; DOI:10.3390/nu9090934.

Peraturan Kepala BPOM RI Nomor 9 Tahun 2016 Tentang Acuan Label Gizi. 2016

Peraturan Menteri Kesehatan nomor 30 tahun 2013 tentang Pencantuman Informasi Kandungan Gula, Garam dan Lemak serta Pesan Kesehatan untuk Pangan Olahan dan Pangan Siap Saji. 2013.

Perhimpunan Dokter Spesialis Kardiovaskular Indonesia. 2013. Pedoman Tatalaksana Dislipidemia Indonesia. Edisi ke-1.

Ooi EMM, Watts GF, Ng TWK and Barret PHR. 2015. Effect of Dietary Fatty Acids on Human Lipoprotein Metabolism: A Comprehensive Update. Nutrients 2015, 7, 4416-4425; DOI:10.3390/nu7064416.

Qureshi AL, Suri MF, Ahmed S, Nasar A., Divani AA, Kirmani JF. 2006. Regular egg consumption does not increase the risk of stroke and cardiovascular diseases. Med Sci Monit, Vol. 13.

Sandjaja, Budiman B, Harahap H, Ernawati F, Soekatri M, Widodo Y, Sumedi E, Rustan E, Sofia G, Syarief SN and Khouw IT. 2013. Food consumption and nutritional and biochemical status of 0.5-12-year-old Indonesian children: the SEANUTS study. British Journal of Nutrition (2013), 110, S11-S20. DOI:10.1017/S0007114513002109

Schaafsma A, Deurenberg P, Calame W, Heuvel E, Beusekom C, Hautvast J, Sandjaja, Poh BK, Rojroongwasinkul N, Le Nguyen BK, Panam P, and Tan-Khouw I. 2013. Design of the South East Asian Nutrition Survey (SEANUTS): a four-country multistage cluster design study. British Journal of Nutrition (2013), 110, S2-S10. DOI:10.1017/S0007114513002067. 
Senaratne J, Griffith J, MacDonald K, Senaratne MP. 2012 Evidence for cholesterol hyperabsorbers and hyperproducers based on comparative low-density lipoprotein reductions achieved by ezetimibe versus statins. J Cardiopulm Rehabil Prev. 2012 Sep-Oct;32(5):250-4. doi: 10.1097/HCR.0b013e31825d29ee.

Song WO, Kerver JM. 2000. Nutritional contribution of eggs to American diets. J Am Coll Nutr.; 19(5 suppl):556S-562S.

Souza RJ, Mente A., Maroleanu A, AI, Cozma HV, Kishibe T, Uleryk E., Budylowski P, Schünemann H., Beyene J., Anand SS. 2015. Intake of saturated and trans unsaturated fatty acids and risk of all cause mortality, cardiovascular disease, and type 2 diabetes: systematic review and meta-analysis of observational studies. BMJ 2015 Aug 11;351:h3978. DOI: 10.1136/bmj.h3978.

Thompson JL, Manore MM, Vaughan LA. 2011. The Science of Nutrition 2nd edition. Pearson Education Inc, USA.

USDA. 2010. Dietary Guidelines for Americans 2010. 7th edition. www.dietaryguidelines.gov

USDA. 2015. Dietary Guidelines for Americans 2015-2020. 8th edition. www.dietaryguidelines.gov

USDA. 2015. Scientific Report of the 2015 Scientific Guidelines Advisory Committee. Advisory Report to the Secretary of Health and Human Services and the Secretary of Agriculture.

Volk, M. G. 2007. An examination of the evidence supporting the association of dietary cholesterol and saturated fats with the serum cholesterol and development of coronary heart disease. Alternative Medicine Review vol. 12:3.

Wang SS, Lay S, Yu HN, Shen SR. 2016. Dietary guidelines for Chinese residents (2016): Comments and comparisons. J. Zhejiang Univ. Sci. B 2016, 17, 649-656.

Wardlaw, GM, Smith, AM, Lindeman, AK. 2012. Contemporary Nutrition: A Functional Approach 2nd edition. McGraw-Hill, New York.

Weggemans RM, Zock PL, Katan M. 2001. Dietary cholesterol from eggs increases the ratio of total cholesterol to high-density lipoprotein cholesterol in humans: a meta-analysis. Am J Clin Nutr. 73: $885-891$. 